\title{
STRANGERS IN THE LAND AND TRUE LOVERS OF THE NATION: THE FORMATION OF LITHUANIAN- SPEAKING BAPTIST IDENTITY, 1918-1940
}

\author{
LINA TOTH *
}

Scottish Baptist College, Paisley E International Baptist Theological Study Centre, Amsterdam

\begin{abstract}
How does an emerging community of faith develop its identity in the context of a semi-hostile and increasingly nationalistic culture? The story of the early years of Lithuanianspeaking Baptists provides an interesting and informative case study. This article focusses on the formative stage of the Lithuanian-speaking Baptist movement during the interwar period of the independent Republic of Lithuania (1918-1940). It considers four main factors which contributed to the formation of Lithuanian-speaking Baptist identity: different ethnic and cultural groupings amongst Baptists in Lithuania; the role of the global Baptist family in providing both material and ideological support; the community's relationship with the Lithuanian state; and their stance towards the dominant religious context, i.e. the Lithuanian Catholic Church. Out of this dynamic emerges a picture of the particular ways in which these congregations, and especially their leadership, navigated their understanding of loyalty to the Kingdom of God in relation to their belonging to a particular national grouping.
\end{abstract}

KEY WORDS: Lithuania, Baptist identity, national identity, theology of culture

\section{Introduction}

In 1938, the Union of Lithuanian Evangelical Baptist Churches published a long-awaited hymnal for the use of Lithuanian-speaking Baptist communities, titled Evangelijos giesmes [Gospel hymns]. Out of its 223 hymns and songs, only two were set to original Lithuanian tunes. The rest of the hymnal contained mostly Anglo-American hymns and songs, and a few Latvian, German or Russian tunes. The lyrics of only three songs were original; all the rest were translations.

An analysis of the theology reflected in the content of the hymnal would be a worthwhile project in itself (for example, see Andronoviene 2007;

* LINA TOTH (ANDRONOVIENE) (PhD 2012, University of Wales and International Baptist Theological Seminary) is Assistant Principal and Lecturer in Practical Theology at the Scottish Baptist College, University of the West of Scotland, Paisley, and Adjunct Supervisor at the International Baptist Theological Study Centre, Amsterdam. Email: lina.toth@uws.ac.uk. 
Remmel 2007). Here, however, I aim to explore the reasons for such a negligible amount of original content. Some of these reasons were practical rather than theological; yet church music not only reflects, but also shapes the theology of a faith community (McElrath 1990; Andronoviene 2007). Thus, a collection of 'foreign' music with 'foreign' lyrics translated into Lithuanian was an implicit theological statement about the identity of Lithuanianspeaking Baptists.

The story of the hymnal mirrors the dynamics of the developing identity of the Lithuanian Baptist community. The editor noted that there was only one criterion in choosing the hymns: 'they had to contain the gospel of Christ' (Inkenas 1938: i). Nevertheless, there were other, perhaps less conscious, criteria. The American Lithuanian Baptists expressed strong support for the hymnal project, both financially and otherwise (Pirmininko pranešimas 1937: 4; Inkenas 1938: i; Latužis 2009: 149). This support included the provision of the stereotype of the musical notation of an earlier American Lithuanian hymnal, which became the basis of the first part of Evangelijos giesmes. All this was a great help, but in effect it also predetermined the choice of music.

The second part of the hymnal contained lyrics only, with a specification of the tunes which could be found in English, German or Latvian hymnals. In this case, the choice was not limited by the availability of musical notations, yet the absolute majority of hymns were, again, translations. This could not be accidental, and it points to at least two further reasons for the selection. First, it enabled Lithuanian-speaking Baptists to sing with other, more numerous ethnic groups belonging to the Lithuanian Baptist Union, who would have used the same or similar hymns. Secondly, it drew a clear line between the way of life represented by the Baptist 'Gospel hymns' and the rest of society, whose distinct musical tradition was steeped in folk-based tunes. The folk tradition, for example, influenced Lithuanian Catholic liturgical music (Motuzas 2011).

This choice of music illustrated the supranational identity claimed by the emerging Lithuanian Baptist community. The enquiry that follows will focus on Lithuanian-speaking Baptists and will analyse the key factors in the formation of their identity in relation to their belonging to the 'Motherland of Lithuania'. I will first probe the dynamics of the relationships of Lithuanian-speaking Baptists with other, considerably more sizeable, ethnic and cultural groups of Baptists in Lithuania. I will then then explore the dependence of the Baptist leadership on the support and guidance, in theological matters and political stances, provided by Baptist bodies from abroad, particularly the Baptist World Alliance and the American Baptist Foreign Mission Society. Next, I will analyse the relations with the newly established state and its increasingly nationalistic government. Finally, I will map the 
community's attitudes towards the Roman Catholic Church, the religious institution dominating contemporary Lithuanian society and, in many ways, politics.

This study takes as its end point the year 1940, which saw the annexation of the country by the Soviet Union and a drastic disruption of the fragile Baptist beginnings in Lithuania. The storms of World War II, followed by deportations and repression by the Soviet regime, have severely reduced the sources relating to the interwar period. Much of the discussion will be guided by the periodical published by and for Lithuanian-speaking Baptists of the time, Tiesos Draugas [Friend of the Truth]. The periodical represents the official position of the Lithuanian-speaking Baptist leadership (especially that of its editor, but also of other contributors) and the way they sought to be perceived by their readers and the authorities both in relation to Lithuanian Baptist identity and the nature of true patriotism.

Another major source for this study has been the person and the work of Albertas Latužis, both through his published history of Lithuanian Baptists (2009), and personal conversations. Similarly, my deepest thanks go to Ruta Inkenaite, who has located important pieces of material from her personal archive as well as transcribing and translating some of the still extant historical correspondence. [Unless noted otherwise, all translations to English quoted in this article are by the author. Archival materials (or copies of these) used in this study are available through the author.] This documentation provides some further depth to the picture that emerges.

\section{Geopolitical, Cultural and Religious Context of the Baptist Beginnings in Lithuania: Broad Strokes}

As the developments explored in this article are not widely known, a brief introduction to the geopolitical and cultural context is in order. During the period considered here one may speak of two rather different Lithuanias. The first was called Prussian Lithuania, or 'Lithuania Minor'. It consisted of the region around Memel, or Memelland, which had been the eastern part of the Prussian Kingdom and, from 1871, of the unified Germany. Founded by the Teutonic Knights, Memel (today Klaipeda), was situated on the northernmost tip of East Prussia on the eastern shores of the Baltic Sea. In 1923, under controversial circumstances, the region came under the jurisdiction of the new independent Republic of Lithuania, but retained considerable autonomy, not in the least in religious matters (for general background, see Thaler 2001: 528-33; Vareikis 2001: 54-65).

The identity of Prussian Lithuanians was formed in this context, at times under the severe pressure of Germanisation. The religious-cultural context of Memel itself was cosmopolitan. However, the local population was largely 
Protestant, predominantly Lutheran, and with a strong flavour of Pietism, especially in the surrounding villages.

Lithuanians of the second entity, Lithuania Proper (sometimes also called 'Lithuania Major'), spoke the same language, but otherwise had been formed in a strikingly different context. The Grand Duchy of Lithuania had been the last pagan country in Europe, receiving baptism only in 1387. It retained various pagan elements for centuries, which, as with the rest of the Baltic region, resulted in a syncretic form of Catholicism (Ward 1992: 38). There was a brief period of Reformation, mostly promoted by the Lithuanian nobility. However, due to the very successful Jesuit mission in Lithuania, the country soon became Catholic again, with only a few small Reformed and Lutheran islands remaining.

Under Tsarist Russia (1795-1918) the Catholic Church was a vital player nurturing Lithuanian identity and countering the Tsarist suppression of the Lithuanian language (Balkelis 2009: 6). By 1918, when Lithuania proclaimed its independence, Lithuanian identity and Catholicism were tightly connected, with the Catholic Church dominating both the political and cultural life of the new country. Matters became more complicated after the 1926 coup d'état which resulted in hostility towards the Catholic clergy, an increasingly authoritarian rule by the Lithuanian Nationalist Union and eventually a one-party system (Misiunas 1970).

In these cultural and religious contexts, Lithuanian-speaking Baptists negotiated their relations with national-political agents and with Christian bodies. The life of the young Republic was brought to an abrupt end first by Nazi Germany's annexation of Prussian Lithuania in 1939, and the Soviet Union's annexation of the Republic of Lithuania in 1940. The World War II and Communist suppressions drastically changed the course of Lithuanian Baptist development.

\section{Baptist Beginnings in Lithuania}

Several beginnings of Baptists in Lithuania could be identified, depending on whether one chooses a geographical, ethnic, or cultural perspective. Memel is known to be the birthplace of the Baptist movement in the territory of today's Republic of Lithuania; it was also the location of a significant revival amongst predominantly German-speaking believers in the 1840s. At one point, Memel Baptist Church was the largest Baptist community in Continental Europe in terms of membership (Randall 2009: 99). It also developed a vibrant missionary identity-in the words of Der Sendbote, the periodical of the German Baptists in America, this church was the 'Antioch' of the Baltic region (cited in Wardin 2013: 41). In the 1860s, it was the catalyst for the birth of the Baptist movement in Latvia (Latužis 2009: 50; Teraudkalns 1999: 224). Furthermore, the ministry of Martin Kalweit, a 
member of Memel Baptist Church, is associated with Baptist beginnings in Russian Transcaucasia (Coleman 2007: 24; Randall 2009: 87-88).

Thirteen years after the founding of the congregation, the Great Fire of 1854 which ravaged Memel, signalled the beginning of an intentional Baptist mission among Lithuanian speakers, beyond the German-speaking population. With most schools and churches suddenly left without buildings, Memel Baptists opened their doors to a day school, a Lutheran congregation and some of those who were left homeless (Missionsblatt 1854, cited in Lysenkaite 2001: 18). Soon more than 640 Lithuanians were attending the services. Karl Albrecht, who was tasked with the evangelisation of Lithuanians (Latužis 2009: 50), described the phenomenon:

The work of grace which has for some time been strikingly going on among the Lithuanians is, I rejoice to say, progressing... The people, naturally warmhearted and frank, seem of later years to have been prepared still more to receive the truth. Wherever I appear, great joy is manifested... Often loud weeping and exclamations interrupted my speech; but there was never undue excitement (Journal of C. Albrecht 1860: 36-37).

Although services in Lithuanian were regularly held until 1939, Lithuanian speakers remained a minority in the life of the church. Memel Baptists were German-speaking, and the identity of the congregation as a whole was that of Germanic Baptists. Even after the region was joined to the Republic of Lithuania in 1923, Memel Baptists retained their membership in the East Prussian Baptist Association. Although the relationship with the emerging union of the Baptist communities in Lithuania Proper was mostly friendly, Memel Baptist participation in the activities of this union was principally that of a friendly neighbour.

Another beginning point would be the Lithuanian-speaking congregations in Prussian Lithuania. Aided by the missionary efforts of the Memel Baptist Church, a Lithuanian-speaking congregation (the oldest of the kind in the region) was established in 1876 in Poškai, followed by another two in 1881 and 1902 respectively (Latužis 2009: 35-37). The members of all three of these congregations were originally Lutheran. The same would be true of the first Latvian-speaking Baptist churches in the territory of Lithuania Proper. The first of these Latvian-speaking congregations was formed in 1865 in Ruzgai, followed by another five later, although some of them later dissolved or merged.

In 1923, J. H. Rushbrooke, at that time European Commissioner of the Baptist World Alliance, observed that whilst Lithuanian Latvians had been reached, the Baptists 'failed to gain any considerable influence among the Lithuanians' in Lithuania Proper (Rushbrooke 1923: 117). Rushbrooke mentioned the German- and Russian-speaking Baptists in Kowno (today 
Kaunas), the temporary capital of independent Lithuania, but, he commented, 'it is unfortunate that... there is as yet no Baptist preacher appealing directly to the masses in their own language' (Rushbrooke 1923: 117). Indeed, the Baptist congregation in Kaunas was founded in 1889 and was primarily working among the German-speaking population of the town. One could also mention a multicultural congregation, founded in 1912, in the official Lithuanian capital of Vilnius. However, this congregation did not have any Lithuanian-speaking members at that time, and as from 1919 to 1940 the region was occupied by Poland, the members had no wider Baptist relations in Lithuania (Latužis 2009: 54-60).

In the words of Teodoras Gerikas, a Lithuanian Baptist leader, before 1918 'all efforts to work amongst Lithuanians [in Lithuania Proper] had been fruitless' (Gerikas 1937: 6). Thus, the last point in tracing Lithuanian Baptist beginnings would be the founding of the first two Lithuanianspeaking congregations in Lithuania Proper, in Biržai and Panevėžys in 1918. Other small Lithuanian-speaking congregations emerged in 1923, 1932, 1933 and 1938; most of them had no more than 10-15 members (Latužis 2009: 109).

In this tiny group of Lithuanian-speaking Baptists in the territory of Lithuania Proper, of particular importance is Teodoras Gerikas, the son of a Latvian mother and a Lithuanian Catholic father, who became a Baptist whilst living in Latvia. Gerikas was educated at the Hamburg Baptist Seminary, and then was enabled, by British Baptists and especially by the American Baptist Foreign Mission Society, to work as a travelling missionary, encouraging the Baptist movement in Lithuania Proper. Rushbrooke wrote: 'The modesty, tact, and skill of Gerikas have within a few years won general recognition, and the earliest results of his labour are full of promise' (Rushbrooke 1929: 78). Most of the Lithuanian Baptist activities can be directly linked to the work of this one remarkable person. With his knowledge of Lithuanian, Latvian, German, Russian and English, he was the central figure in the slow unification of the Baptist groupings scattered across the country, the main representative of the Baptists in dealings with the government, the primary link for relations with Baptists abroad, and the editor and publisher of a Lithuanian Baptist periodical. As Latužis notes, 'without this servant of God it is not likely that the Baptists of Lithuania [of the time] would have managed the difficult path towards unity and common ministry' (Latužis 2009: 121).

\section{Ethnic Diversity and Integration Efforts}

After 1918, and especially after 1923, when Memelland was incorporated into the territory of the Republic of Lithuania, links with the congregations in Prussian Lithuania began to materialise, and the first discussions took 
place regarding the unification of Baptists in Lithuania. However, the creation of one single Baptist union turned out to be a challenging task. As noted, before 1918 the Latvian-speaking congregations belonged to the Latvian Baptist Union; congregations in Prussian Lithuania (both German and Lithuanian speaking) were part of the East Prussian Baptist Association; and Kaunas and all other tiny Baptist groupings were not officially linked to anything (Latužis 2009: 121).

Gerikas' idea was to unite isolated groupings and individual Lithuanianspeaking believers into a 'virtual' Baptist congregation which he called 'Diaspora' (Gerikas 1937: 7; Latužis 2009: 123). His intent was to create a sense of belonging, even though all the members of this Diaspora would never gather in one place. Support for the development of common links also came from some Memellander Germans and Prussian Lithuanians, who in 1923 organised a festival for the Baptists of the two different parts of the new country-Prussian Lithuania and Lithuania Proper-to get to know each other (Latužis 2009: 123). However, support for Gerikas' idea was not unanimous.

Whilst reluctant to discuss the founding of a Baptist union, given their belonging to the East Prussian Baptist Association, German Baptists in Prussian Lithuania, nevertheless, saw value in some kind of alliance. Latvianspeaking congregations first opposed the idea-fearing that Germans would comprise the majority in the new union and they would likely dictate its terms. Gerikas focused on cultivating informal links by visits and correspondence. This turned out to be an effective strategy, and later on the Latvian-speaking congregations adopted a more positive attitude towards the idea of a union, including regular financial contributions (Latužis 2009: 124-126).

In the meantime, a different body was found in 1923-the Lithuanian Baptist Mission Work Union (LBMWU). The purposes of LBMWU were to cultivate relationships between Baptists and represent Baptist causes to governmental offices (Latužis 2009: 125-126). A small monthly magazine of evangelistic and informative nature in Lithuanian, Tiesos Draugas [Friend of the Truth], was established. The magazine was published from 1924-1940; almost all issues were edited by Gerikas. The Council of LBMWU consisted of three German speakers and four Lithuanians, with Otto Ekkelman, the minister of Memel Baptist Church, as chairman. LBMWU organised annual conferences. A Prussian Lithuanian Baptist described the 1932 conference: 'Here we truly understood how it was in the first Christian gathering in Jerusalem, about which it is written: They began to speak in different tongues.> German, Lithuanian, Russian, and Latvian were spoken and sung. In spite of different languages, the spirit of unity blew throughout the whole meeting' (cited in Latužis 2009: 129). 
The Union of Lithuanian Evangelical Baptist Churches was officially founded in 1933-after ten years of building relationships in the context of LBMWU. Eventually, the Union included most of the congregations in the territory of unified Lithuania, with the exception of two German speaking congregations in Prussian Lithuania. The proportion of Lithuanian speakers in the Union remained strikingly small. In 1930, there were more than 1040 Baptists in Lithuania, but only about 200 of them were of Lithuanian nationality, and out of these, only about 60 resided in Lithuania Proper (Gerikas 1930c: 3). The work amongst Lithuanian speakers in Lithuania Proper remained very modest, both in terms of the reception of the message by the general population and the enthusiasm of the existing churches, with a palpable frustration articulated by those at the core of this effort (Gerikas 1932: 4).

Tensions on ethnic grounds loomed in the background, and would at times flare up, especially between the Lithuanians and the Germans. The latter were losing numbers due to the emigration of German speakers to Germany and experienced restrictions imposed by the Lithuanian government (Pirmininko pranešimas 1937). After the departure of a pastor who was sympathetic to mission amongst Lithuanian speakers, the new minister of Memel Baptist Church insisted that a newly converted Lithuanianspeaking family join Memel Baptists, rather than a Lithuanian congregation situated further from their home. 'Order is order', he asserted (Valys 1935). Discontent was apparent also in the German-speaking congregation in Kaunas. A 1929 letter by Gerikas describes the problem:

[The minister of Kaunas German-speaking congregation] Brother Freutel does not want to have anything in common with me. He says: ...'You have become a great Lithuanian patriot and do not consider the matters of the society'... You know very well that I want to live in peace with everybody. But brother Freutel, it seems, is not happy to see Lithuanians in action. He would like them to consult the Germans in all matters (Gerikas 1929).

In spite of this private complaint, Gerikas continued to devote much of his energy to building cooperation between all the congregations. These efforts bore fruit. However, keeping the bonds of peace among different ethnic groups likely meant sacrificing bolder, intentional attempts of developing an authentically Lithuanian Baptist form of life. Explicit discussions regarding the need for developing a Lithuanian Baptist identity are largely missing from the record, but correspondence and other sources indicate the awareness of such a need. Speaking at the Baltic Baptist gathering in Riga in 1937, Gerikas noted that there were a number people offering themselves to come and work in Lithuania-but in his understanding, 'they do not understand our language and the soul of our nation, our spirit' (Gerikas 1937: 
9). Similarly, referring to the possible relocation of a Prussian Lithuanian missionary to Lithuania Proper, he privately commented: 'Let us see. He is too German, but perhaps he will improve' (Gerikas 1930a).

The country's annexation by the Soviet Union in 1940, and the Nazi occupation and war-time that followed would have shaken the sturdiest of structures, but in the case of the Baptist Union of Lithuania it was even more evident that the fragile work towards unity was given too short of a time to put down roots. On the other hand, the level of activity of this small body, through the person of Gerikas in particular, was truly remarkable in the interwar period. This was to a great extent due to the support received from the Baptist family beyond Lithuania-the next factor to be considered in this study.

\section{The Influence of World Baptists in the Formation of Lithuanian Baptist Identity}

Two Baptist bodies have been crucially important in providing material support and moral guidance for the Lithuanian Baptist community: Baptist World Alliance (BWA) and the American Baptist Foreign Mission Society (ABFMS). Given the small scale of the Lithuanian movement, the frequency of visits and intensity of correspondence between Lithuanian Baptist leadership and Baptists abroad is rather striking. This would be particularly true in relation to Walter O. Lewis, ABFMS Representative in Europe. In a personal letter Gerikas noted that Lewis-who Gerikas sometimes privately called 'uncle Lewis'-'said that this was one of the most important mission fields. For us his [recent] visit brought great joy' (Gerikas 1930c). Given that all of the countries surrounding Lithuania had considerably higher numbers of Baptists, the interest in one of the last mission fields in Europe is understandable.

Links were also formed with a handful of American Lithuanians, especially those involved in a small Lithuanian Baptist congregation in Peabody, Massachusetts. They later became the main sponsors of the publication of the Evangelijos giesmes hymnal. Ties existed also with a few Lithuanians in Brazil and elsewhere. Such contacts were especially important for the production of Tiesos Draugas. After the first twelve issues, the editorial of the magazine thanked 'all the friends and collaborators... in Major and Minor Lithuania, Latvia, America, England, Germany, Estonia, and Brazil' (Editor 1925a: 4).

In maintaining and developing international relations, the role of Gerikas was crucial (Latužis 2009: 166). Gerikas' participation in the 1923 BWA congress in Stockholm laid the beginning for the relationship with the BWA; it was almost certainly during this congress that he met Rushbrooke as the European Commissioner of the BWA (later to become its General 
Secretary). Gerikas also took part in the 1928 congress in Toronto and, in 1934, with another eleven representatives from Lithuania, he was present at the Baptist Congress in Berlin. Rushbrooke is mentioned as the first person who helped to provide financial support for the publication of Tiesos Draugas (Editor 1925b: 4).

ABFMS financially supported Lithuanian Baptists in a variety of ways. Full sponsorship for three young Lithuanian Baptists at Newton Theological Institution, Massachusetts, was granted in the early 1930s. As late as 1938 Gerikas' own support, as well as that of at least one other worker, Jonas Inkenas, was almost solely dependent on ABFMS (Gerikas 1938). Both Rushbrooke and Lewis visited Lithuania on a number of occasions. It could be queried whether such heavy reliance on financial support might have resulted in dictates from abroad, with the Lithuanian Baptists functioning as the 'agents' of the foreign bodies. However, in historical documentation, there is no evidence of this being the case. There does not seem to be a hint of pressure in any matter of policy or action in the letters from the representatives of BWA and ABFMS. The strongest words in the records were the insistence that Gerikas take better care of his fragile health (Lewis 1931).

What is evident is a strong desire of the Lithuanian Baptist leadership to make use of the advice and guidance available from abroad, in relation to theological issues as well as various political and ethical questions arising in those volatile interwar years. BWA overviews of the key issues facing the Baptists of the world were published in Tiesos Draugas at least once a year, and at times more frequently. These letters raised concerns such as the threat of war, stressing the importance of the Baptist contribution in peacemaking, and they insisted on the equality and value of any ethnicity and race in the Kingdom of God. This became particularly significant in the 1930s, as the Fascist voices both within and outside Lithuania gained prominence.

Alongside the financial help of the ABFMS, the moral support of the BWA was a significant factor in the continuation of the Baptist Union in Lithuania. It gave a voice and strength to the tiny Lithuanian-speaking minority who could now see themselves as part of the larger body, and it provided theological grounds for better understanding the multicultural nature of their union. The portrayal of the Lithuanian Baptists in Tiesos Draugas, the annual greetings, reports and other sources had a strong emphasis on the Lithuanian Baptists belonging to a global Baptist movement. Positively, it provided a counter-balance to the parochial nature of much of the religious discourse in interwar Lithuania. Yet there remained the challenge of Lithuanian Baptists finding a legitimate place in the newly established Republic of Lithuania. 


\section{Increasing Nationalism and Lithuanian Baptist Attitudes to the State}

The first issue of Tiesos Draugas, published in January 1924, started with a greeting to 'all the sons and daughters of Major and Minor Lithuania, villagers and town dwellers'. The publication invited its readers 'to join the work for our beloved Motherland Lithuania, which is as if risen from the dead' (V 1924a: 1). A sense of hopefulness and excitement is evident, as is an intention of challenging the Baptist believers to work for the harmony and benefit of the Motherland. 'Being free in our Motherland in the political aspect, we have to strive for spiritual freedom...' (V 1924a: 1).

The overall respect for the institution of the government remained unwavering throughout all the issues of Tiesos Draugas—although, as will be demonstrated, not without complaints regarding the unequal treatment of the Baptists compared to the Catholic Church. However, gratitude was expressed to the government for cheaper public transport tariffs for larger Baptist gatherings, or the waver of the tax for Bibles imported from abroad. The latter news, announced in 1925, was followed by urging 'the believers to pray for the Government, as this is what the Holy Scripture teaches, 1 Timothy 2:1-3' (Editor 1925d: 4). Whilst negative comments were made about bitter fights between the political parties, support for democracy and encouragement to participate in the elections were clearly voiced (G 1926: 1-2). As it happened, the elections of 1926 were the last before a coup d'état which launched a dictatorial regime of ten years without access to the ballot box.

On some occasions, the president of the country, Antanas Smetona, is referred to as the 'Leader of the Nation' in Tiesos Draugas, as was typical in the Lithuanian press of the time. For the 20th anniversary of Lithuania's independence, the first page of Tiesos Draugas — which often went without a single photo in the whole issue-was entirely dedicated to a photo of the 'Leader of the Nation' (Dvidešimtasias 1938: 1). The next page emphasised the Lithuanian Baptists' love for the country:

Today we want to tell you openly with all others, Motherland Lithuania: we love you!... We thank God for the freedom and progress you made during these last twenty years. And we want to continue working for your welfare... Our beloved Mother Lithuania, keep justice and truth in all matters! Do not forget those of your sons who are the smallest and being hurt' (Dvidešimtasias 1938: 2).

Further on, evoking the multi-confessional and multi-religious climate of the Grand Duchy of Lithuania during the reign of the Vytautas the Great, the editor emphasised the Duke's tolerance and respect for 'human rights' - certainly an anachronistic observation, but one which made use of the dominant identity narrative of interwar Lithuania and applied a theological reinterpretation to it. 
However, concern for human rights was expressed only in relation to the Baptists' freedom of worship; any other observations about the politics in Lithuania were avoided (G 1927: 4). When an American Lithuanian missionary, Antanas Gilys (Gillies) was granted permission by the Ministry of Education to come to Lithuania as a 'Baptist priest', it was on the understanding that he would 'stay away from any politics and would devote [his] time only to the matters of faith' (Gillies 1937).

Nevertheless, both German fascism and Soviet communism of the early 1930 s were occasionally referred to negatively. The publication was critical of Russia's introduction of a continuous production week (a five-day, and later six-day week calendar) which made it impossible for the churches to have Sunday as a common day for worship (Laišku děžutė 1930: 4). The readers were reminded to be grateful for 'the freedom of faith which we possess in our beloved Lithuania' (Tikinčiujų vargai 1931: 4).

Regardless of the insistence on keeping away from politics, indirect comments about growing Lithuanian nationalism can, however, be traced in Tiesos Draugas. Positive remarks on loyalty to one's nation are accompanied by persistent qualification of this sentiment in the context of the allencompassing nature of the Kingdom of God, especially in the later years of intensifying nationalism. A 1940 statement by Gerikas is worth quoting at length:

Our confession of faith demands all its members to be decent and honest people and in their earthly life to be faithful citizens of their State... God has placed us in our nation. We have to seek its wellbeing in everything and everywhere. We have to live in such a way that our nation would feel that within it there is a group of people who love it, who pray for it, who desire its success and work for that success. Nobody can take away this feeling from us. And we do not want to take it away from others. But national feelings shouldn't enslave us either. They shouldn't make us chauvinists, unhealthy ultra-patriots. God is the God of all... True Christianity does not forbid either national feelings or internationalism, but of its followers it doesn't make some kind of new Internationale... Christianity is not national or international; it is supra-national - it is universal (G 1940: 11-12; original emphasis).

While insisting that 'as Christ's followers we know that his kingdom is not of this world', the articles in the publication also emphasised 'the wellbeing of the country in which we live' (G 1927: 4). Several aspects of the wellbeing were seen especially worthy of support, such as the Lithuanian Sobriety Movement, 'Blaivioji Lietuva' [Sober Lithuania], though such initiatives were considered to be only partially effective: 'It is good and necessary to fight against bad habits, but that is not enough. One must reach the roots... Whom Christ liberates, that person becomes free, not only from bad habits, but also from bad inclinations' (Blaivioji Lietuva 1937: 25). 
Lithuania's moving towards an increasingly authoritarian regime in the 1930s introduced additional restrictions. In December 1936, Gerikas complained at length, with palpable frustration, about the changes in the law which in fact reinstated the old Tsarist Russian regulation that for the registration of churches (church buildings) a minimum of 25 members were required to sign the application. Given how thinly spread Lithuanianspeaking Baptists were, these new-old regulations had an especially negative effect on the dispersed congregations in Lithuania Proper. Although the tone of this long editorial was conciliatory, Gerikas' frustration regarding the actions of the authorities was unambiguous (Iš redaktoriaus krepšio 1936: 7-8).

Another feature of the church-state relationship in interwar Lithuania was the fact that, from 1918 to 1940, Lithuania Proper did not have a civil registry. The reasons for this were the dominance of the Catholic Church and its opposition to the introduction of a civil registry, and the silent agreement of the Catholic majority in society (see Laukaityte 2013: 105122). This created serious difficulties for those belonging to 'unrecognised' religions as well as non-religious persons, in terms of legally marrying, registering their children and burying their dead. Thus, one of the pressing matters of the Baptist Union was legal recognition of the Baptist Registry Centre in Kaunas, established in 1931-1932 (Latužis 2009: 137). The Centre, run by Gerikas, eased the situation for all Baptists in Lithuania Proper, but demanded a lot of his time (Gerikas 1930b).

Beside civil registry matters there were other issues that hindered Baptist work. The 1937 report to the Annual Convention of the Union noted that local 'officials have received orders to forbid evangelical Baptists to act without the express permission of the Ministry of Education, and the local Police departments have been ordered to check if these requirements are followed' (Chairman's Report 1937). An official permit from the Ministry of Education had to be obtained for organising larger gatherings, such as annual meetings of the congregational delegates. Police had to be provided with the text of the main address which was read during the gathering (Gerikas 1939). On the other hand, rather diplomatically, Gerikas chose to express his hope that such changes were part of the state's reorganisation, the goal of which was to grant such groups as Baptists rights equal to other churches (Chairman's Report 1937). However, equality of rights was de facto impossible given the dominance and power exercised by the Lithuanian Catholic Church of the time.

\section{Lithuanian Baptist Relations with the Catholic Church}

I have already referred to the importance of the Catholic Church and the 'Lithuanian Catholic faith', in reviving and sustaining Lithuanian identity 
under the Tsarist regime. Lithuanian identity as unquestionably Catholic continued to play a key part in the shaping of the national consciousness during Lithuania's independence. The Catholic context without doubt influenced the formation of the Lithuanian-speaking Baptist identity, even if by the way of negative identity-Baptists being 'not Catholic'. Yet the picture is more complex. Especially in the earlier issues of Tiesos Draugas, there were regular attempts to find inspiration for good practice and teaching from other churches, including the Catholic Church of Lithuania. For example, a poem was reprinted from the Catholic periodical $\breve{S} v$. Pranciškaus varpelis [The Bell of St Francis] (cited in Naruševičius 1925: 1). Two issues later, the editor of Tiesos Draugas reflected on the fact that $\check{S}_{v}$. Pranciškaus varpelis was forbidding its readers to read Protestant-and Baptistpublications, but Tiesos Draugas 'has never yet quarreled or ridiculed anybody. It strives to fight against godlessness and sin by preaching Christ's love. Its co-workers are believers from different Protestant churches, as well as Catholics with a living faith' (Editor 1925c: 4). There was clearly a broad vision, though based on the notion of 'living faith'.

What was seen by Lithuanian Baptists to be the absence of 'living faith' in the Catholic tradition, and what featured as their most common criticism, was the ignorance of the Bible (G 1924). Similarly, sadness was expressed for what was perceived to be the lack of the spirit, and discrepancies in the practice of true gospel in the life and the teaching of the Catholic Church: 'Wake up, priestly leaders of the nation! Proclaim the genuine truth of the Gospel to the nation! Show by your deeds what you proclaim with words!' (G 1925). A direct relationship between being Lithuanian and being Catholic was also questioned by Baptists: 'Not all Catholics [in Lithuania] are good Lithuanians. There are among them various types, those who have become quite Polish, and others' (G 1940: 11).

In contrast to the early years, the stance in Tiesos Draugas towards the Catholic Church grew more forceful. A report on the conversion to Baptist faith of a Brazilian Catholic priest Jose Marcelino Nunes de Araujo stated: 'I became dead to Catholicism' (Šviesos keliu 1932: 4). The reason for the change of tone can be gleaned from the Lithuanian report to the Convention of Baltic Baptists in Tallinn in 1930: 'Our state's constitution recognises equal rights to all religious organisations, but the Catholic Church hates us' (Lietuvos sveikinimas 1930: 3). This certainly was corroborated by the Lithuanian Catholic press of the time which regularly warned the readers against 'Biblists [Jehovah's Witnesses], Baptists and other pioneers of godlessness'. 'We cannot permit Lithuania to become a Protestant or Communist country’ (Šaduikis 1931: 87).

Lithuania's Catholic clergy were impacted by the repressive measures implemented by the country's régime, especially during the height of the 
martial law censorship of 1930-1932 (see Kuodys 2013). The censorship affected the Baptists too; starting from the third issue of Tiesos Drangas in 1930 until the fourth issue of 1933, permission by the war censorship authority had to be included in every issue (on the war censorship, see Riaubiene 2005: 103-113.) However, on the local level, the Catholic Church and state authorities often acted in unison, which meant that pressure on Baptists continued. In one of his letters, Gerikas discussed this dynamic in the Telšiai bishopric. In his judgement, there were people in the town who were interested in the Gospel-'but the wee bishop... is very angered. The police keep confiscating the Bibles and other Christian literature, handing them over to the court, and call it antireligious rubbish' (Gerikas 1930c). In some villages and towns, Tiesos Draugas was not passed to the subscribers, as the post office was run by a local priest (G 1931: 4). Even more disturbing were the accounts of priests refusing the burial ceremony for those whom they suspected of links with Baptists (Martinaitis 2005: 1-2).

In the light of the situation, strong criticism of Catholicism could be understandable; yet, with some exceptions, public Lithuanian Baptist discourse made an effort to minimise negative statements and to continue working for peace. To alleviate some of the tensions, humour was also employed. Reflecting on the fact that certain Lithuanian Catholic periodicals issued a warning not to read such 'trash' literature as Tiesos Draugas, Gerikas noted that 'after such advertisement, some people decide to get acquainted with such «trash and as a result encounter genuine Gospel truth. So we are not upset over such advertisement, and indeed are even grateful for costfree announcements about our newspaper's existence' (Iš redakcijos krepšio 1938: 8).

Such animosity and pressure, however, were conducive to the development of a rather categorical Lithuanian Baptist identity with a clear-cut distinction between the ways of 'believers' and those of 'the world', which was seen, even if implicitly, to include much, if not all, of the Catholic Church. In the long run, this did not help inter-church relationships.

\section{'In the World but not of It': Concluding Comments}

An opportunity, as well as an acute need, to forge a Lithuanian way of being a Baptist was clearly recognised in Lithuanian-speaking Baptist life, and frequently, if not necessarily directly, explored in Tiesos Draugas. Indeed, the very commitment to publish Tiesos Draugas in the Lithuanian language-a costly and time-consuming enterprise-was a testament to the vision of an authentically Lithuanian Baptist expression.

The challenges these believers met were manifold: very small numbers of Lithuanian-speaking Baptists and a much larger proportion of nonLithuanian speakers in the Union; dependence on support from abroad; 
the newly established nation state moving towards nationalist dictatorship; and the dominant role of Roman Catholicism in the scene of Lithuanian identity. In the face of intensifying nationalism, the task of constructing a Lithuanian Baptist theology of culture involved navigating an increasing tension between love for one's nation ( $G$ 1927: 4) and an insistence on the ultimate citizenship in the heavenly Kingdom (G 1940: 12). As nationalist sentiments advanced, the growing emphasis of Lithuanian-speaking Baptists on building bridges of peace is evident in different occasions of communication, especially in the editorials of Tiesos Draugas.

Returning to the case explored in the beginning of this article, it is in such a context that the choices which accompanied the publication of the hymnal Evangelijos giesmes become clearer. Both being rooted in Lithuanian culture and language and being part of international Baptist networks were highly valued. Tiesos Draugas frequently emphasised the importance of the style and quality of the Lithuanian language, whether in the translated or original texts. Meanwhile, the foreign origin of the tunes signified an allegiance greater than that of the Lithuanian nation state. These melodies also firmly linked this small believers' community to the wider family of Baptists, both within and without the country, and communicated Lithuanian Baptists' intention to be part of the global Baptist body.

The identity of the Lithuanian-speaking Baptists-particularly as articulated by their leader, Teodoras Gerikas-was being constructed in a very limited time and under swiftly changing circumstances. One could only conjecture how Lithuanian Baptist relations with the cultural context had further developed if Lithuania had not suffered a brutal change in circumstances after only twenty-two years of existence-a change that required an almost complete restart of the Lithuanian Baptist life after the World War II. As it stands, the story of the Lithuanian Baptist movement of the interwar years is a case study of the challenges which can be faced by any emerging community of faith in an adverse national and religious environment.

\section{Bibliography}

Andronoviene L (2007) As Songs Turn into Life and Life into Songs: On the First-Order Theology of Baptist Hymnody. In Jones KG and Parushev PR (eds) Currents in Baptistic Theology of Worship. Prague: International Baptist Theological Seminary, pp. 129-141.

Atleisk! [Forgive!] (1932) Tiesos Draugas 9(8-9): 6.

Balkelis T (2009) The Making of Modern Lithuania. London and New York:

Routledge.

Blaivioji Lietuva [Sober Lithuania] (1937) Jaunystei žydint 3-4(*): 25. 
Coleman HJ (2007) Baptist Beginnings in Russia and Ukraine. Baptist History and Heritage 42(1): 24-36.

Editor [Teodoras Gerikas] (1925a) Laišku dėžutė [Letter box]. Tiesos Draugas 2(1): 4 .

Editor [Teodoras Gerikas] (1925b) Laiškų dèžutė [Letter box]. Tiesos Draugas 2(3): 4 .

Editor [Teodoras Gerikas] (1925c) Laiškų dėžutė [Letter box]. Tiesos Draugas 2(5): 4.

Editor [Teodoras Gerikas] (1925d) Laiškų dėžutė [Letter box]. Tiesos Draugas 2(7): 4 .

Dryža, Br (1932) Laiškų dėžutė [Letter box]. Tiesos Draugas 9(5): 4.

Dvidešimtasias Nepriklausomos Lietuvos Sukaktuves Švenčiant [Celebrating the 20th Anniversary of Independent Lithuania] (1938) Tiesos Draugas 15(2): 1.

G (1935) Palaiminti taikieji [Blessed are the peace makers]. Tiesos Draugas 12(11): 1-3.

Gerikas T (1929) Letter to Jonas Inkenas, 13 November.

Gerikas T (1930a) Letter to Jonas Inkenas, 18 February.

Gerikas T (1930b) Letter to Jonas Inkenas, 14 April.

Gerikas T (1930c) Letter to Jonas Inkenas, 30 June.

Gerikas T (1930d) Lietuvos sveikinimas Talino suvažiavime [Lithuania's greeting at Tallinn convention]. Tiesos Draugas 7(10): 3.

Gerikas T (1937) Baptistų darbas Lietuvoje [Baptist work in Lithuania]. Tiesos Draugas 14(8-9): 5-9.

Gerikas T (1938) Letter to Jonas Inkenas, February (n.d.).

Gerikas T (1939) Postcard to Jonas Inkenas, 2 June.

G T [Teodoras Gerikas] (1924) Knygu knyga [The Book of books]. Tiesos Draugas 1(5): 2.

G T [Teodoras Gerikas] (1925) Ant Vytauto kalno [On Vytautas' hill]. Tiesos Draugas 2(8): 2.

G T [Teodoras Gerikas] (1926) Išsirink ką nori [Elect whom you want]. Tiesos Draugas 3(5): 1-2.

G T [Teodoras Gerikas] (1927) Laišku dėžutė [Letter Box]. Tiesos Draugas 4(2): 4.

G T [Teodoras Gerikas] (1931) Apžvalga [Overview]. Tiesos Draugas 8(10): 34.

G T [Teodoras Gerikas] (1932) Mūsų suvažiavimas Kaune [Our convention in Kaunas]. Tiesos Draugas 9(7): 4.

G T [Teodoras Gerikas] (1937) Iš darbo lauko [From the field work]. Tiesos Draugas 14(8-9): 10-13.

G T [Teodoras Gerikas] (1940) Tikyba ir tautybė [Faith and nationality]. Tiesos Draugas 17(2): 10-12. 
Gillies AJ (1937) Letter to the Ministry of Education of the Department of Faiths of the Republic of Lithuania, 16 March.

Inkenas J, ed (1938) Evangelijos giesmès [Gospel hymns]. Šiauliai: LEBDS.

Iš redaktoriaus krepšio [From the basket of the editor] (1936) Tiesos Draugas 13(12): 7-8.

Iš redakcijos krepšio [From the basket of the editor] (1938) Tiesos Draugas 15(3): 8.

Journal of C. Albrecht, Lithuania. The Work in Lithuania (1860) American Baptist Missionary Magazine 40(*): 36-37.

Jurgaitis M (1924) Rytmečio giesmė [Morning song]. Translation from German. Tiesos Draugas 1(11): 4.

Kuodys M (2013) Karo padèties represinių priemonių panaudojimas priěs katalikiškają opoziciją Lietuvoje 1930-1932 m. [Martial law as an instrument of oppression against the Catholic opposition in Lithuania (19301932)]. Soter 47(75): 19-30

Laiškų déžutė [Letter box] (1930) Tiesos Draugas 7(2): 4.

Latužis A (2009) Po Jo Sparnais: Baptistu istorija Lietuvoje 1841-1990 [Under His Wings: Baptist History in Lithuania 1841-1990]. Klaipėda: Eglè.

Laukaityte R (2013) Society Without a Civil Registry (1918-1940): Outcomes and Consequences. Lithuanian Historical Studies 18(*): 105-122.

Lietuvos ev. baptistų drauguomeniu $1938 \mathrm{~m}$. statistika [The statistics of Lithuanian evangelical Baptist congregations for 1938] (1938) Tiesos Draugas 16(6): 4 .

Lietuvos sveikinimas Talino suvažiavime [Lithuania's greeting at Tallinn convention] (1930) Tiesos Draugas 7(10): 3.

Lewi WO (1931) Letter to Jonas Inkenas, 17 July.

Lysenkaite R (2001) Baptist Beginnings in the Baltic Countries: the Case of the Church in Memel. Unpublished master's thesis, International Baptist Theological Seminary, Prague.

Martinaitis P (2005) Prisiminimai iš vaikystės dienų [Memories from childhood days]. Private manuscript, 12 April. Available through the author.

McElrath HT (1990) The Hymnbook as a Compendium of Theology. Review and Expositor 87(1): 11-31.

Misiuna RJ (1970) Fascist Tendencies in Lithuania. The Slavonic and East European Review 48(110): 88-109.

Motuzas A (2011) Lietuvos Kalvarijų kryžiaus kelių giesmių literatūrinių ir muzikinių tekstų kilmè: vietos ar atneštinè tradicija? [The origin of the lyrics and music of Lithuanian Calvary Cross songs: Local or imported tradition?]. Lituanistica 57(1): 81-92.

Naruševičius J (1925) Žmonès užimti be galo... [People are endlessly busy...]. Tiesos Draugas 2(3): 1. 
Randall IM (2009) Communities of Conviction: Baptist Beginnings in Europe. Schwarzenfeld: Neufeld Verlag.

Pirmininko pranešimas metiniame Evangelikų baptistų drauguomenių suvažiavime [Chairman's Report for the Annual Convention of the Union of Evangelical Baptist churches] (1937) Included in the Minutes, 14 June. Available through the author.

Remmel M (2007) The Ausbund as a Source and Expression of Anabaptist Primary Theology and Moral Sense of Virtue. In Jones KG and Parushev PR (eds) Currents in Baptist Theology and Worship Today. Prague: International Baptist Theological Seminary, pp. 143-180.

Riaubienè A (2005) Valstybinès cenzūros mechanizmas tarpukario Lietuvoje [The mechanism of state censorship in interwar Lithuania]. Knygotyra 44(*): 103-113 (abstract in English).

Rushbrooke JH (1923) The Baptist Movement in the Continent of Europe. London: Kingsgate Press.

Rushbrooke JH (1929) Some Chapters of European Baptist History. London: Kingston Press.

Šaduikis Č (1931) Vilkai avies kailyje [Wolves in sheep's clothing]. Vienybe [Unity] 16(11): 87.

Šviesos keliu [Walking the way of light] (1932) Tiesos Draugas 9(4): 4.

Teraudkalns V (1999) Latvian Baptist Traditions in Transition. Religion, State E Society 27(2): 223-232.

Thaler P (2001) Fluid Identities in Central European Borderlands. European History Quarterly 31(*): 519-548.

Tikinčiujų vargai Sovietų Rusijoje [Believers' Woes in Soviet Russia] (1931) Tiesos Draugas 8(8): 4.

Valys J (1935) Letter to Jonas Inkenas, 10 March.

Vareikis V (2001) Memellander / Klaipėdiškiai Identity and GermanLithuanian Relations in Lithuania Minor in the Nineteenth and Twentieth Centuries. Sociologija. Mintis ir veiksmas 6(1-2): 54-65, http://www.ku.lt/wp-content/uploads/2013/03/2001_nr_1-2.54-65.pdf (Accessed 30 March 2015).

V P [Petras Variakojis] (1924a) Pro angą žengiant [Stepping through the opening]. Tiesos Draugas 1(1): n.p.

V P [Petras Variakojis] (1924b) Ką tu myli? [What do you love?]. Tiesos Draugas 2(1): 2-3.

Ward WR (1992) The Protestant Evangelical Awakening. Cambridge: Cambridge University Press.

Wardin A (2013) On the Edge: Baptists and Other Free Church Evangelicals in Tsarist Russia, 1855-1917. Eugene, OR: Wipf \& Stock. 